\title{
Tujuh Kebajikan Utama Untuk Membangun Karakter Kristiani Anak
}

\author{
Kalis Stevanus \\ Sekolah Tinggi Teologi Tawangmangu \\ kalisstevanus91@gmail.com
}

\begin{abstract}
Character is something that is very important for human progress, both individually and in a nation. This article motivated by the decline of the character of society that appears in the rampant crime, anarchism, vigilante, radicalism, hatred, intolerance, disrespect, terrorism, injustice which is causing violence in various human relationships. Individual and social clashes occurred which are always based on the society background, such as ethnicity, religion and social condition. It cannot be denied if it is said that the root of all this is caused by character problem. Character influences ethical and moral judgment and decision making. By this context, Christian families are called to participate in building the nation through education in family. Christian families become character educators for their children. This article aims to describe seven virtues main, namely compassion, empathy, self-mastery, respect, tolerance, fairness, and patriotism to build child Christian character.
\end{abstract}

Keywords: character, christian, child, main virtue

\begin{abstract}
Abstrak: Karakter adalah suatu hal yang sangat penting bagi kemajuan manusia, baik secara individual maupun suatu bangsa. Tulisan ini dimotivasi oleh merosotnya karakter masyarakat yang nampak dalam maraknya tindakan kejahatan, anarkhis, main hakim sendiri, radikalisme, kebencian, intoleransi, rasa tidak hormat, terorisme, ketidakadilan, sehingga menyebabkan membudayanya kekerasan dalam berbagai relasi. Terjadi perbenturan-perbenturan individual dan social yang masih selalu terkait dengan latar belakang masyarakat, seperti etnis, agama dan keadaan social. Tidak dapat disanggah bila dikatakan akar penyebab semua itu disebabkan oleh problem karakter. Karakter memengaruhi pertimbangan dan pengambilan keputusan etis dan moral. Dalam konteks inilah keluarga Kristen dipanggil untuk turut serta membangun bangsa melalui pendidikan di keluarga. Keluarga Kristen menjadi pendidik karakter bagi anak-anaknya. Tulisan ini bertujuan mendiskripsikan tujuh kebajikan utama, yaitu belas kasih, empati, penguasaan diri, rasa hormat, toleransi, adil, dan cinta tanah air, untuk membangun karakter Kristiani anak.
\end{abstract}

Kata-kata kunci: karakter, kristiani, anak, kebajikan utama 


\section{A. Pendahuluan}

Karakter merupakan persoalan sangat penting dalam hidup manusia baik bagi kehidupan individu maupun social bahkan bangsa. Seperti yang dikatakan Willy Susilo bahwa perihal karakter menjadi topik pembicaraan yang tidak pernah usang. Topik ini diperbincangkan di banyak kalangan, mulai dari orang awam, ilmuwan, bahkan negarawan, bahwa karakter adalah suatu hal yang sangat penting bagi kemajuan manusia, secara individual maupun suatu bangsa. ${ }^{1}$ Thomas Lickona seorang pakar Pendidikan Karakter dari Amerika Serikat menyatakan bahwa ukuran kemajuan suatu negara bukanlah besarnya pendapatan nasional, kemajuan teknologi, atau kekuatan militernya, melainkan karakter penduduknya. ${ }^{2}$

Bangsa Indonesia kini sedang menghadapi persoalan-persoalan besar, maraknya kejahatan, korupsi, tindakan anarkhis, main hakim sendiri, maraknya budaya kekerasan, radikalisme, intoleransi, dan sebagainya. Juga terkikisnya nilainilai luhur bangsa karena pengaruh asing, semakin kuatnya pengaruh budaya media (media culture) sebagai pembentuk nilai-nilai para orang muda. Orang-orang muda dibombardir dengan acara televisi, film, music, video, permainan, dan internet yang menunjukkan kekerasan, kejahatan, kekejaman, dan sebagainya.

Apa sesungguhnya akar penyebab semua itu? Tidak dapat disanggah bila dikatakan bahwa hal itu disebabkan oleh problem karakter. Benar yang dikatakan David 0. Dykes, bahwa krisis yang paling mengkuatirkan dan signifikan yang dihadapi dalam negara dan keluarga saat ini bukanlah dalam bidang ekonomi atau politik, melainkan krisis karakter. ${ }^{3}$ Hal ini tidak dibantah oleh pemerintah Indonesia. Dalam pengantar Naskah Akademik Pendidikan Karakter di Perguruan Tinggi, Dirjen Dikti mengatakan bahwa "kami menyadari saat ini bangsa Indonesia tengah menghadapi krisis multidimensional, dan krisis tersebut diyakini bermula dan lemahnya karakter yang dimiliki oleh masyarakat dan bangsa kita. ${ }^{4}$ Itu sebabnya pemerintah Indonesia mengambil inisiatif untuk memberi perhatian utama kepada pembangunan karakter bangsa.

Itu sebabnya mengapa Pendidikan Karakter sangat penting (urgent) dilakukan agar masyarakat bisa membedakan mana yang benar dan mana yang salah, sehingga mereka dapat menangkis pengaruh buruk dari luar. Pemerosotan karakter (character deterioration) di tengah masyarakat dan bangsa Indonesia ini, mestilah membuat kita prihatin dan berupaya menanggulanginya karena itu adalah tanggung jawab kita bersama. Hal inilah yang menggugah penulis mengangkat judul "Tujuh Kebajikan Utama Untuk Membangun Karakter Kristiani Anak" dengan tujuan untuk memberi kontribusi bagi pendidik dalam Pendidikan Agama Kristen (PAK) khususnya di dalam konteks keluarga. Namun, tidak menutup kemungkinan juga pendidik PAK di dalam

\footnotetext{
1 Willy Susilo, Membangun Karakter Unggul (Yogyakarta: Andi, 2013), 22.

2 Michele Borba, Membangun Kecerdasan Moral (Jakarta: Gramedia, 2008), x.

3 David O. Dykes, Character Out of Chaos (Jakarta: Metanoia, 2007), ix.

4 Daniel Nuhamara, "Pengutamaan Dimensi Karakter Dalam Pendidikan Agama Kristen", Jurnal Jaffray, Vol. 16, No. 1, (April 2018): 97.
} 
konteks Gereja maupun pada konteks sekolah formal, untuk kemajuan manusia, baik secara individual maupun suatu bangsa.

\section{B. Pengertian Karakter}

Dalam kehidupan sehari-hari sering kita mendengar istilah karakter. Ada yang menyebutnya watak dan perangai. Yang lain menamainya budi pekerti. Ada pula yang menggunakan istilah akhlak dan untuk yang baik disebut akhlak mulia. Dalam makalah ini istilah itu digunakan secara bergantian. Tetapi apakah maksud dari kata ini? The New International Webster's Student Dictionary of the English Language menerangkan istilah berarti tanda (mark) atau cap (stamp), karakter berarti kualitas atau kebiasaan yang membedakan seseorang dari orang lainnya. ${ }^{5}$ Menurut A. Setiono Mangoenprasodjo dan Sri Nur Hidayati, karakter adalah keyakinan terhadap system benar atau salah yang dikombinasikan dengan kemauan untuk melakukan yang benar tanpa pamrih. Karakter berkaitan dengan hati nurani atau suara hati (inner). Orang yang berkarakter adalah orang yang berpikir, bersikap, dan bertindak berdasarkan suara hati. ${ }^{6}$ Sedangkan istilah karakter sendiri berasal dari bahasa Yunani yaitu charassein yang berarti mengukir, melukis, memahatkan, atau menggoreskan. Apa yang hendak ditekankan di sini bahwa karakter adalah suatu tindakan sengaja untuk membentuknya layaknya tindakan memahat dan mengukir. Karakter mengacu pada pemotongan dan pengukiran yang tidak dilakukan hanya sekali tetapi sepanjang hidup. Karakter dikembangkan sepanjang hidup seseorang, tetapi landasan karakter diletakkan dalam pelatihan moral sejak anak usia dini melalui kebiasaan yang dibentuk oleh otoritas dan disiplin.

Secara singkat dapat dikemukakan bahwa istilah karakter mengandung arti sifat-sifat atau kebiasaan-kebiasaan dalam diri dan kehidupan kita yang telah tertanam dan berakar, serta telah menjadi ciri khas diri kita sendiri. Sifat dan kebiasaan itu tetap menjadi ciri khas diri kita apakah dilihat orang atau pun tidak. Pendapat yang tidak jauh berbeda dikemukakan David W. Gill yang dikutip Daniel Nuhamara bahwa karakter adalah apa dan siapa kita - apakah orang lain melihat kita atau tidak. ${ }^{7}$

\section{Tujuh Kebajikan Utama untuk Membangun Karakter Kristiani Anak}

Peradaban suatu masyarakat bahkan bangsa tidak dapat dipisahkan dari peran keluarga. Kita tahu bahwa secara keseluruhan, baik tradisi/adat istiadat, keyakinan, tata krama, nilai-nilai moral, ditransfer lewat keluarga kepada generasigenerasi berikutnya. Keluarga merupakan fondasi atau pembentuk nilai-nilai moral atau kebajikan suatu masyarakat. Sebagai lembaga terkecil dalam masyarakat, keluarga memegang peran yang sangat penting dalam kehidupan sosial umat manusia. Seperti yang diungkapkan oleh Dick Iverson bahwa keluarga adalah unit

\footnotetext{
5 The New International Webster's Student Dictionary of the English Language (1996:42).

${ }^{6}$ A. Setiono Mangoenprasodjo dan Sri Nur Hidayati, Anak Masa Depan dengan Multi Intelegensi (Yogyakarta: Pradipta Publishing, 2005), 140.

7 Nuhamara, Pengutamaan Dimens Karakter, 99.
} 
dasar seluruh masyarakat. Keluarga adalah batu penjuru, atas mana segala sesuatu dibangun. ${ }^{8}$ Amaliyah Ulfah mengemukakan bahwa karakter yang kuat sangat penting untuk membangun peradaban bangsa. ${ }^{9}$

Olehnya, untuk berhasil memperbarui karakter masyarakat, maka harus memulainya dari keluarga. Keluarga adalah sekolah pertama bagi anak dan ayah ibu (orangtua) sebagai pendidik secara alamiah, sedangkan anak sebagai pembelajar alamiah. Karakter atau budi pekerti perlu dibentuk dan dibina sejak usia dini. Kegagalan membangun karakter anak di usia dini akan menghasilkan pribadi yang bermasalah di masa dewasanya.

Ratna Megawangi, direktur eksekutif Institut Pengembangan Pendidikan Holistik Indonesia Heritage Foundation, menuturkan bahwa untuk mendidik anak agar memiliki karakter diperlukan proses "mengukir", yakni melalui pengasuhan dan pendidikan yang tepat. Dan ini harus dilakukan sejak anak dilahirkan atau sejak dini. Untuk mewujudkannya bagi anak-anak prasekolah, mereka perlu dididik dan diperkenalkan pada aspek perilaku kebajikan, diajari nilai-nilai moral, bahkan empati terhadap kesulitan dan penderitaan orang lain. ${ }^{10}$ Juga dikatakan A. Setiono Mangoenprasodjo dan Sri Nur Hidayati bahwa orangtualah yang paling berperan dalam membentuk karakter dan kepribadian anak. Peran sekolah hanyalah 20\%, karena pembentukan karakter dimulai sejak anak masih kecil dan terus berproses hingga dewasa. Sekolah hanya penyeimbang, walaupun tidak mengabaikan pendidikan karakter anak melalui peran sekolah formal. ${ }^{11}$

Dikemukakan Johana Manubey, I Nyoman Sudana Degeng, Dedi Kuswandi bahwa untuk membangun karakter sangat baik jika dilakukan sejak masih kanakkanak. Tempat untuk mengajarkan karakter itu dimulai dari keluarga. ${ }^{12}$ Pendapat Paul D. Meier yang dikutip B.S. Sidjabat, menyebutkan bahwa sekitar 80-85\% dari watak dasar ${ }^{13}$ seseorang merupakan hasil belajar selama enam tahun pertama dalam kehidupan. Dan sisanya terbentuk dan berkembang dalam perjalanan hidup berikutnya di masa remaja, pemuda dan dewasa. Tingkah laku; kelakuan yang dipelajari dalam tahun-tahun berikutnya dibangun di atas pola-pola dasar kebiasaan yang sudah tertanam sebelumnya di masa kanak-kanak. ${ }^{14}$ Banyak pakar mengatakan usia dini merupakan masa kritis bagi pembentukan karakter seseorang. Apalagi anak

${ }^{8}$ Dick Iverson, dkk., Memulihkan Keluarga (Jakarta: Harvest Publication House, 1991), 1.

${ }_{9}^{9}$ Amaliyah Ulfah, "Pengembangan Subject Specific Pedagogy (SSP) Tematik Berbasis Local

Wisdom Untuk Membangun Karakter Hormat dan Kepedulian Siswa SD”, Scholaria: Jurnal Pendidikan dan Kebudayaan, Vol.8, No. 1, (Januari 2018):17.

${ }^{10}$ A. Setiono Mangoenprasodjo dan Sri Nur Hidayati, Anak Masa Depan dengan Multi Intelegensi (Yogyakarta: Pradipta Publishing, 2005), 95.

11 Mangoenprasodjo dan Hidayati, Anak Masa, 136.

12 Johana Manubey, I Nyoman Sudana Degeng, Dedi Kuswandi “Pengembangan Bahan Ajar Untuk Menumbuhkan Kelemahlembutan di Sekolah Minggu" Jurnal Pendidikan: Teori, Penelitian, dan Pengembangan Vol.1 No.3 (Maret 2016): 526.

13 Watak adalah sifat batin manusia yang memengaruhi segenap pikiran dan ringkah laku; budi pekerti; tabiat (Lihat, KBBI). Jadi, yang dimaksud watak dasar adalah karakter bawaan dari lahir, selaku sifat yang turun dari gen ayah dan ibu ke anaknya yang sifatnya dominan.

${ }^{14}$ Sidjabat, "Spiritualitas dan Pembentukan Karakter," Jurnal Pengarah, (Juli 2010):43. 
usia dini termasuk dalam golden age, tahap ini merupakan tahap terbaik perkembangan fisik dan otak anak. ${ }^{15}$

Keluarga terus memainkan peran kunci dalam membentuk kepribadian seorang anak sebagai generasi penerus masyarakat dan juga bangsa. Keluarga sampai kapan pun tetap menjadi pusat atau sentral di mana nilai-nilai dan pola kehidupan seseorang terbentuk (Ul 6:4-9). Keluarga adalah tempat seseorang belajar, dengan cara yang paling praktis dan konkrit. Keluarga adalah tempat yang paling baik untuk pendidikan. Tidak ada tempat pendidikan yang lain, baik yang didirikan oleh pemerintah atau institusi lain, yang dapat menggantikan keluarga. Pendidikan di sekolah hanya membantu atau menambah apa yang kurang, yang dilakukan oleh orangtua, tetapi bukan untuk menggantikannya. Pendidikan di luar rumah hanyalah "pelengkap" pendidikan yang telah didasarkan di keluarga. ${ }^{16}$

Orangtua diberi tugas oleh Tuhan untuk mendidik anak-anaknya: “... didiklah mereka di dalam ajaran dan nasihat Tuhan" (Ef 6:4). Andar Ismail menyatakan : kualitas pribadi dan moral seseorang adalah produk dari masa kecil. Kualitas tabiat dan sifat juga adalah produk masa kecil. Jadi masa kecil adalah masa peletakan dasar atau fondasi kepribadian dan moral seseorang. ${ }^{17}$

Makalah ini membahas tujuh kebajikan utama, yaitu belas kasih, empati, penguasaan diri, rasa hormat, toleransi, adil, dan cinta tanah air untuk membangun karakter Kristiani Anak. Karena itu, tulisan ini ingin memberi tekanan pada peran keluarga Kristen untuk membangun karakter Kristiani anak sehingga mereka dapat berpikir, bersikap dan bertindak atau bertingkah laku yang baik sesuai nilai-nilai Kristiani sepanjang hidup mereka.

\section{Belas kasih}

Firman Allah mengajar kita agar hidup saling mengasihi,"Jikalau seorang berkata: 'Aku mengasihi Allah, dan ia membenci saudaranya, maka ia adalah pendusta ... barangsiapa mengasihi Allah, ia harus juga mengasihi saudaranya” (1 Yoh.4:20-21). Kata "saudara" di sini tidak boleh dimaknai secara sempit dan dangkal hanya sebatas sekeluarga maupun seagama, tetapi dalam arti luas bahwa semua orang adalah sebagai sesama, sebagai ciptaan Allah yang membawa rupa dan gambar Allah (imago Dei) Sang Khalik (Kej.1:26, 27).

Banyak budaya zaman dulu mempunyai pandangan yang sempit tentang sesama manusia. Dalam budaya itu sesama manusia terbatas hanya pada orang yang sebangsa atau seagama. Mereka merasa lebih aman dengan lingkungan bangsa atau budaya sendiri. Orang yang berbeda dengan mereka dianggap "orang asing". Pandangan sempit itu hingga kini masih ada walaupun masyarakat dalam banyak negara sudah semakin majemuk.

\footnotetext{
15 Amaliyah Ulfah, "Pengembangan Subject Specific Pedagogy (SSP) Tematik Berbasis Local Wisdom Untuk Membangun Karakter Hormat dan Kepedulian Siswa SD”, Scholaria: Jurnal Pendidikan dan Kebudayaan 8, No. 1, (Januari 2018):17.

${ }^{16}$ Kalis Stevanus, Mendidik Anak (Yogyakarta: Lumela, 2018), 2.

17 Andar Ismail, Selamat Menabur (Jakarta: BPK Gunung Mulia, 2007), 117.
} 
Siapakah sebenarnya sesama kita? Pernah orang mengajukan pertanyaan itu kepada Tuhan Yesus. Lalu Ia menjawab dengan sebuah cerita. Ia memakai pendekatan perumpamaan: perumpamaan orang Samaria yang murah hati (Luk.10:25-37). Salah seorang pendengar-Nya adalah seorang ahli Taurat bertanya kepada-Nya tentang apakah kaidah paling utama dalam kehidupan yang bermutu. ${ }^{18}$ Ia membalas pertanyaan itu dengan balik bertanya,"Apa yang tertulis dalam hukum Taurat? Apa yang kau baca di sana?" (ayat.26). Ahli Taurat itu langsung mengutip Kaidah Kasih tentang mengasihi Allah dan mengasihi sesama manusia. Tuhan Yesus membenarkan jawab itu dan menyuruh dia mempraktikkannya. Namun ahli Taurat itu belum puas lalu bertanya lagi,"Dan siapakah sesamaku manusia" (ayat.29). Yang menjadi sesama manusia adalah "orang yang tergerak hatinya oleh belas kasihan" dan "yang menunjukkan belas kasihan". Yang menolong adalah jutsru orang yang bukan sebangsa dan seagama, yaitu orang Samaria. Di sini Tuhan Yesus dengan tegas menjawab melalui perumpamaan orang Samaria yang murah hati bahwa sesama manusia itu ternyata bukan hanya sesama agama dan sebangsa (seperti pemahaman orang Yahudi pada waktu itu), melainkan juga mereka yang berbeda bangsa dan beragama lain.

Yohanes Krismantyo Susanta menuturkan bahwa melalui perumpamaan tersebut, secara tidak langsung, Tuhan Yesus bukan saja menjawab pertanyaan "siapakah sesamaku" tetapi bagaimana menjadi sesama manusia bagi orang lain (bahkan musuh sekalipun). Melalui perumpamaan tersebut, Tuhan Yesus mendorong para murid dan pengikut-Nya untuk menjadi seorang sahabat yang ramah tamah tanpa membeda-bedakan orang berdasarkan latar belakang budaya dan kepercayaan. 19

Tuhan Yesus memakai perumpamaan orang Samaria yang murah hati (Luk. 10:25-37) tersebut hendak menegaskan pengajaran Tuhan Yesus tentang sikap moral yang harus dibangun oleh orang Kristen terhadap sesama. Perumpamaan tersebut merupakan gambaran kasih yang besar. Tuhan Yesus menempatkan orang Samaria sebagai pemberi kasih yang besar tanpa pamrih bagi orang Yahudi yang sama dibenci juga oleh bangsa-Nya. Dengan membangun konsep belaskasihan, Tuhan Yesus menanggapi realitas kehidupan yang ditandai dengan berbagai pergumulan sosial dari orang-orang yang terpinggirkan, kaum miskin, kaum menderita, kaum perempuan dan anak-anak, bahkan kepada kaum atau bangsa yang dianggap kafir oleh orang Yahudi. ${ }^{20}$

${ }^{18}$ Hidup bermutu identik dengan hidup yang kekal (Luk.10:25; bdk. Yoh.14:6; 17:3). Kata hidup di sini ditulis dalam bahasa Yunaninya adalah zoe, suatu hidup yang bermutu.

${ }^{19}$ Yohanes Krismantyo Susanta, "Persahabatan sebagai Tema Teologis dan Implikasinya Bagi Kehidupan Bergereja” Jurnal Dunamis:Jurnal Teologi dan Pendidikan Kristiani 2, no. 2, April 2018: 10. http://www.sttintheos.ac.id/e-journal/index.php/dunamis/article/view/169/132 (diakses 16 November 2018).

20 I Made Suardana,"Identitas Kristen Dalam Realitas Hidup Berbelaskasihan: Memaknai Kisah Orang Samaria yang Murah Hati" Jurnal Jaffray 13, no.1, April 2015: 125-126 http://ojs.sttjaffray.ac.id/index.php/JJV71/article/view/115 (diakses 16 November 2018). 
Kelompok etnik Yahudi dan etnik Samaria adalah sama-sama orang Israel namun terpisah oleh tembok prasangka. Sudah ratusan tahun terdapat tembok prasangka rasial dan religius antara orang Yahudi dan orang Samaria. Orang Yahudi menghina orang Samaria, sebaliknya orang Samaria membenci orang Yahudi. Tembok prasangka rasial dan religius telah ditembus dan diruntuhkan oleh Tuhan Yesus di depan mata kedua belas murid-Nya yang adalah orang Yahudi dan di depan mata penduduk orang Samaria itu. ${ }^{21}$

Terobosan itu terjadi karena belas kasihan-Nya yang besar yang melahirkan jiwa besar. Di dalam perumpamaan itu, orang Samaria berjiwa besar karena ia menolong pihak lawan (orang Yahudi). Tetapi ada seorang lagi yang juga berjiwa besar dalam cerita ini, yakni Tuhan Yesus sendiri. Ia memuji pihak lawan (orang Samaria). Sebenarnya Tuhan Yesus bisa menempatkan orang Samaria sebagai tokoh jahat dalam alur cerita (bukankah beberapa hari sebelumnya Tuhan Yesus ditolak oleh orang Samaria, Luk.9:51-56) dan dengan demikian lebih memanaskan dan menambahkan kebencian terhadap orang Samaria. Tetapi Tuhan Yesus justru berjiwa besar. Sebab itu Ia menampilkan orang Samaria sebagai tokoh yang berjiwa besar. Tujuan-Nya adalah agar pendengar juga belajar berjiwa besar. Inilah yang disebut Andar Ismail sebuah Pendidikan Kedamaian (peace education) ${ }^{22}$ yang lahir dari hati yang penuh belaskasihan. Tuhan Yesus adalah Pelayan pendamaian,"Allah dengan perantaraan Kristus telah mendamaikan kita dengan diri-Nya ...” (2 Kor.5:18).

Lalu sebagai tindak lanjutnya Allah menyuruh umat-Nya meneruskan pelayanan pendamaian ini. Hal itu jelas dikatakan di ayat 19: "Ia telah mempercayakan berita pendamaian itu kepada kami”. Pelayanan pendamaian adalah menerima tiap orang sebagaimana adanya dengan pelbagai perbedaan yang dimilikinya.

Gaya hidup berbelas kasihan itu dipraktekkan sehari-hari oleh Tuhan Yesus. Tuhan Yesus berhati belas kasihan. Dari hati yang penuh belas kasihan timbul empati. Ia sangat empati dengan orang yang berada dalam kesakitan dan kelemahan. Matius mencatat,"Melihat orang banyak itu, tergeraklah hati Yesus oleh belas kasihan kepada mereka, karena mereka lelah dan terlantar ... " (Mat.9:36). Itulah jiwa Tuhan Yesus tentang sesama manusia. Yesus melayani semua orang melampaui batasan keluarga, kerabat, suku, bangsa, budaya, agama atau batas apa pun lainnya. Belas kasihan merupakan kekuatan moral yang membebaskan seseorang dari belenggu pandangan sempit tentang sesama kita.

Hidup menjadi damai timbul dari sikap saling mengasihi (berbelas kasihan) dengan memandang semua orang sebagai saudara atau sesama. Tuhan Yesus hidup dalam masyarakat yang memendam kebencian karena prasangka antara orang Yahudi dan Samaria. Namun Tuhan Yesus tidak pernah menghasut atau ikut memanaskan suasana permusuhan. Sebaliknya Ia meruntuhkan prasangka tersebut untuk menciptakan kedamaian. Kata-Nya,"Berbahagialah orang yang membawa damai ... “ (Mat.5:9). Semangat demikian seharusnya dimiliki oleh orang Kristen

${ }^{21}$ Andar Ismail, Selamat Sejahtera (Jakarta: BPK Gunung Mulia, 2005), 48.

22 Ibid., 49. 
dalam mengembangkan dan mewujudnyatakan perdamaian tanpa memandang latar belakang budaya, iman dan kepercayaan serta memperlakukan orang lain sebagai sesama dan sahabat.

Tindak belas kasihan bersumber pada kasih Allah semata sebab kasih itu berasal dari Allah. Firman Allah berkata,"Jikalau Allah sedemikian mengasihi kita, maka haruslah kita juga saling mengasihi" (1 Yoh.4:10). Hendaklah orang Kristen meneladani Tuhan Yesus menerapkan prinsip hidup berbelas kasihan kepada semua orang tanpa pandang bulu. Prinsip berbelas kasihan mendatangkan sikap empati terhadap orang lain-orang lain sebagai saudara (sahabat) dan sesama yang juga sama-sama menyandang rupa dan gambar Allah (imago Dei).

\section{Empati}

Michele Borba mendefinisikan empati adalah kemampuan memahami dan merasakan kekuatiran orang lain. ${ }^{23}$ Empati merupakan inti karakter yang membantu anak memahami perasaan orang lain. Kebajikan ini membuatnya menjadi peka terhadap kebutuhan dan perasaan orang lain serta mendorongnya memperlakukan orang lain dengan welas asih sebagai sesama sehingga mencegahnya melakukan tindakan yang dapat melukai orang lain.

Jadi berempati merupakan pelindung terbaik anak dari tindak kekerasan, kekejaman, kebiadaban, dan keegosian. Empati tumbuh secara alamiah dan sejak usia dini. Meskipun anak-anak lahir dengan kapasitas berempati, namun empati tetap ditumbuhkan karena jika tidak, tak akan berkembang. Berikut langkah orangtua menumbuhkan empati dalam diri anak:

2.1 Membantu Anak Memahami Emosi dan Meningkatkan Perbendaharaan Kata yang Berkaitan Dengan Emosi, sehingga Ia Dapat Memahami Perasaan Orang Lain.

Anak dibantu memahami perasaan orang lain (bahwa orang lain merasa tidak nyaman, cemas, bangga, senang, atau marah) dengan mengidentifikasi dan mengekspresikan emosinya. Ia juga perlu pendidikan yang memperkuat pemahaman anak terhadap emosi, dengan memperluas kosakata emosi dan mendorongnya untuk menggunakannya. Untuk meningkatkan kosakata ungkapan emosi, dapat dilakukan dengan menggunakan ungkapan dan pertanyaan yang membantu anak memahami perasaan, misalnya,"Sepertinya kamu sedang (tegang, marah, kuatir). Ada apa? Setelah kosakata ungkapan emosi meningkat, sering-seringlah mengajukan pertanyaan,"Bagaimana perasaanmu?" atau "Menurutmu, bagaimana perasaannya?" sehingga dapat memahami perasaaan diri sendiri, barulah empati anak akan berkembang karena sudah dapat memahami perasaan orang lain. ${ }^{24}$

\subsection{Meningkatkan Kepekaan Terhadap Perasaan Orang Lain}

23 Borba, Membangun Kecerdasan, 21.

${ }^{24}$ Ibid., 24, 25. 
Salah Satu cara terbaik membuat anak lebih peka terhadap perasaan orang lain adalah dengan mengungkapkan perasaan orangtua sendiri, misalnya," Ibu senang sekali melihat kamu menyayangi adik" atau "Ayah kesal sekali; kemarin tukang di rumah bilang ongkos perbaikan kamar mandi adalah satu juta, dan sekarang mereka bilang lebih dari itu."

\subsection{Mengembangkan Empati Terhadap Sudut Pandang Orang Lain}

Bantu anak mengidentifikasi perasaan orang lain dengan menyuruhnya membayangkan apa yang dirasakan orang tersebut dalam kondisi tertentu dari sudut pandang anak. Mintalah anak menempatkan dirinya pada posisi orang tersebut. Dengan membantu anak membayangkan perasaan dan pikiran orang lain sehingga ia benar-benar mampu memahami dan merasakan perasaan orang lain.

\subsection{Orangtua harus menunjukkan perilaku empati}

Mengajarkan perilaku empati (berbela rasa) kepada anak tidak sama pengaruhnya dibandingkan orangtua sendiri menunjukkan perilaku tersebut. Orangtua harus menjadikan kesehariannya sebagai contoh nyata perilaku empati tersebut agar anak bisa secara langsung melihatnya. Dengan sering anak melihat kepedulian (empati) orangtua terhadap perasaan orang lain yang dalam kesusahan dan kesulitan, serta orangtua perlu melakukan sesuatu untuk membantu anak, sehingga anak dapat meniru perbuatannya. Ini cara yang paling baik membantu anak "menangkap" perilaku empati tersebut serta mau menerapkannya dalam hidup mereka kini maupun di masa mendatang.

Hal inilah yang dituntut dari kehidupan kekristenan, dalam keberadaan apa pun dan di manapun, menampilkan hidup berbela rasa (empati), dan memedulikan sesama sebagai wujud mengasihi sesama.

\section{Penguasaan Diri}

Penguasaan diri atau kontrol diri penting untuk membantu anak melakukan tindakan bermoral. Disadari atau tidak, banyak terjadi tindak kejahatan yang dilakukan seseorang diakibatkan tidak adanya mekanisme dari dalam yang disebut "penguasaan diri", yang mencegah dia melakukan dorongan-dorongan jahat yang muncul di pikirannya.

Definisi penguasaan diri atau kontrol diri (self control) adalah mengendalikan pikiran dan tindakan agar dapat menahan dorongan dari dalam maupun dari luar sehingga dapat bertindak dengan benar. ${ }^{25}$ Michele Borba menyebut kontrol diri sebagai mekanisme internal yang sangat berpengaruh, yang mengarahkan sikap moral anak, sehingga pilihan yang mereka ambil tidak hanya aman, tetapi juga bijak.

${ }^{25}$ Borba, Membangun Kecerdasan, 9. 
Kontrol merupakan kekuatan moral yang secara sementara menghentikan tindakan yang berbahaya. ${ }^{26}$

Itu sebabnya orangtua perlu mendorong tumbuhnya penguasaan diri dalam diri anak sehingga anak dapat mengerem perilakunya dan tidak akan melakukan tindakan yang berbahaya. Orangtua tidak cukup hanya mengajari anak mengetahui dan merasakan hal yang baik dan benar, tetapi juga mengajari mereka bertindak bijak dan benar. Sebab memberi contoh adalah cara terbaik mengajari anak menguasai diri. Orangtua perlu memperbaiki perilakunya sehingga dapat memberi contoh penguasaan diri yang baik bagi anak dan menunjukkan bahwa hal tersebut merupakan prioritas. Jadi, penguasaan diri merupakan sikap yang sangat penting bagi seseorang untuk dapat mengontrol dorongan, keinginan atau godaan agar berpikir sebelum bertindak.

\section{Rasa Hormat}

Rasa hormat adalah menghargai orang lain dengan berlaku baik dan sopan. ${ }^{27}$ Salah satu bentuk rasa hormat adalah berlaku sopan santun yaitu menghargai orang lain. Firman Allah berkata,"Hormatilah ayahmu dan ibumu-ini adalah suatu perintah yang penting ... supaya kamu berbahagia dan panjang umurmu di bumi" (Ef.6:2). Anak harus diajar memiliki rasa hormat terhadap orangtua. Anak yang tidak diajar untuk menghormati orangtua, ia tidak akan belajar menghargai orang lain dengan sopan santun atau tata krama.

Untuk menumbuhkan rasa hormat di dalam diri anak, agar anak bisa menghargai orang lain, maka ia terlebih dahulu harus belajar menghargai dirinya. Dan ini hanya bisa terjadi jika anak dihargai. Olehnya, orangtua perlu membangun hubungan yang hangat, baik, dan sopan santun terhadap anak. Orangtua harus jadi panutan yang baik. Jika anak tidak dihargai, bagaimana ia bisa menghargai orang lain? Karena sikap orangtua, anak melihat bahwa orangtua menyayangi, menghornati, dan menghargai mereka.

Jika orangtua memperlakukan anak sebagaimana ia mengharapkan anak menghormatinya, dunia ini akan menjadi lebih bermoral. Anak-anak yang sehari-hari menunjukkan rasa hormat cenderung lebih menghargai hak orang lain. Menumbuhkan rasa hormat juga perlu untuk membentuk warga negara yang baik dan hubungan interpersonal yang positif. Karena rasa hormat tersebut menuntut agar semua orang sama-sama dihargai dan dihormati, ini dapat mencegah tindak kekerasan, kekasaran, ketidakadilan, kekurangajaran dan kebencian. Berikut sikap orangtua untuk menumbuhkan rasa hormat pada diri anak:28

\subsection{Perlakukan Anak sebagai Orang Terpenting}

Jika orangtua ingin agar anak merasa dihormati, perlakukan dia sebagai orang yang terpenting. Orangtua harus menghargai anaknya sepanjang hari. Kadang-kadang

\footnotetext{
${ }^{26}$ Ibid., 97.

27 Borba, Membangun Kecerdasan, 139.

28 Ibid., 155-159.
} 
bahasa orangtua malah meruntuhkan perasaan harga diri dan nilai anak-anak mereka. Secara tidak sadar orang memandang rendah atau kurang penting karena mereka masih kanak-kanak.

Jadi sebagai orangtua, semestinya menunjukkan betapa penting dan berharganya anak-anak dan kehadiran mereka sungguh-sungguh disambut dengan kasih tanpa syarat sebagai berkat Tuhan di dalam keluarga.

\subsection{Berikan Kasih Sayang Tanpa Syarat.}

Semestinya anak mendapat penghargaan dan kasih sayang tanpa syarat itu sejak lahir. Anak yang berada dalam kasih sayang yang tanpa syarat akan tumbuh dengan rasa percaya diri yang kuat.

Seorang anak perlu merasa bahwa ia diterima sepenuhnya, seadanya dan seutuhnya tanpa kuatir ditolak. Hal ini menolong terbentuknya suatu dasar bagi rasa percaya diri. ${ }^{29}$ Dalam berbagai situasi, anak harus merasa bahwa orangtua akan selalu ada untuk membantu anak apa pun yang terjadi-dan ini merupakan kasih yang diperlukan anak agar merasa dihormati. Anak tahu bahwa orangtua mengasihinya dengan kasih tidak bersyarat. ${ }^{30}$

\subsection{Dengarkan Dengan Penuh Perhatian dan Penghargaan}

Sering kali anak tidak mendengarkan kata-kata orangtua, dan lebih memerhatikan sikap, gerak-gerik, ekspresi wajah, dan nada bicara. Orangtua harus mengomunikasikan rasa hormat ketika berbicara dengan anak. Ketika anak berbicara, orangtua harus benar-benar mau mendengarkan. Mendengarkan dengan penuh perhatian merupakan cara yang baik untuk menunjukkan rasa hormat.

\section{Toleransi}

Toleransi adalah sikap menghargai apa yang diyakini orang lain. Toleransi adalah menghormati martabat dan hak semua orang meskipun keyakinan dan perilaku mereka berbeda dengan kita. ${ }^{31}$ Dengan demikian, toleransi menuntut seseorang menghargai "perbedaan" dengan memperlakukan orang lain secara baik, hormat dan penuh pengertian (tenggang rasa).

Thomas Lickona mendefinisikan toleransi di dalam bukunya Raising Good Children, yang dikutip Michele Borba bahwa toleransi sebagai kebajikan etis mempunyai dua aspek: pertama adalah rasa hormat terhadap martabat manusia dan hak asasi setiap orang. Meskipun hati nurani kita tidak dapat menerima pilihan orang lain atau bahkan berusaha meyakinkan mereka bahwa itu salah, toleransi akan mencegah kita dari tindakan pemaksaan pendapat terhadap orang lain atau secara tidak adil membatasi kebebasan mereka. Toleransi membuat kita dapat sepakat untuk tidak sependapat. Kedua adalah menghargai keragaman manusia yang

${ }^{29}$ Stevanus, Menjadi Orangtua Bijak, 111.

${ }^{30}$ Borba, Membangun Kecerdasan, 157.

31 Ibid., 9. 
memiliki latar belakang, suku, agama, negara, dan budaya yang berbeda. Toleransi dalam hal ini berarti melihat sisi baik dari setiap manusia. ${ }^{32}$

Apakah Tuhan Yesus mengajarkan toleransi? Dikisahkan di dalam Lukas 9:5156, ketika sebuah desa Samaria menolak Tuhan Yesus-baik sebagai orang Yahudi maupun karena ajaran-Nya, Ia memarahi murid-murid-Nya yang ingin menghancurkan desa tersebut. Ini menunjukkan sikap Tuhan Yesus yang sangat "toleran" dan mengasihi bahkan terhadap orang-orang yang menolak-Nya. Dalam konteks kehidupan bersama di tengah masyarakat yang plural, orang Kristen dipanggil untuk mengembangkan etika kehidupan bermasyarakat yang ditandai dengan sikap saling menerima dan menghormati dalam kasih tanpa mengorbankan keunikan Yesus sebagai the only way (Yoh.14:6). Sikap saling menerima dan menghormati artinya manusia harus memiliki pandangan dan sikap yang terbuka terhadap kepelbagaian. Mempertahankan pandangan dan sikap hidup yang tertutup, dan kaku berakibat menghancurkan dan mencederai kehidupan. Orang Kristen patut mengembangkan sikap hidup yang toleransi atau tenggang rasa terhadap kepercayaan lain.

\section{Adil}

Gejala yang semakin mengkuatirkan di masyarakat, di mana orang lebih menonjolkan semangat kompetisi, tetapi mengabaikan atau bertentangan prinsip keadilan. Tanpa keadilan akan semakin memupuk atau meningkatkan perbuatan curang yang didasari oleh sifat atau mental keegoisan (berusaha menang dengan segala cara). Keadilan dapat diartikan tidak memihak, dan bertindak adil.

Stephen Tong mengatakan bahwa keadilan merupakan dasar dalam mendidik anak. Kebutuhan anak bukan saja kasih, tetapi juga keadilan. Tanpa keadilan, pendidikan baik di rumah maupun di sekolah akan gagal. ${ }^{33}$ James Dobson, pakar keluarga mengatakan bahwa persaingan (kompetisi) keluarga akan menjadi buruk sekali bila tidak ada keadilan yang ditegakkan dalam keluarga. ${ }^{34}$ Di sinilah peran orangtua harus banyak memberi contoh keadilan kepada anak-anak dalam kehidupan sehari-hari. Hanya mengajarkan keadilan kepada anak tidak akan membuat anak menjadi bersikap adil. Bukan perilaku anak yang diperhatikan, melainkan perilaku orangtua sendiri. Orangtua dapat menumbuhkan keadilan sejak dini dalam pola asuh. Semakin dini menumbuhkan keadilan pada anak, semakin besar kemungkinan menjadikan keadilan sebagai kebiasaan sehari-hari, yang selalu mengarahkan anak dalam bertindak. Langkah tersebut adalah pertama: orangtua harus menunjukkan keadilan kepada anak-anak mereka dengan memperlakukan secara adil. Orangtua harus bersikap bijak dan adil dalam menyatakan kasih kepada semua anak-anaknya. Kasih tanpa disertai keadilan hanya akan menghasilkan sifat manja dan egois. Anak bisa muncul kepahitan dan kebencian terhadap orangtua maupun saudaranya sendiri. Bisa juga melahirkan sikap saling bermusuhan, pertikaian, kecurangan,

\footnotetext{
32 Ibid., 225.

33 Stephen Tong, Membesarkan Anak Dalam Tuhan (Jakarta: LRII, 1997), 24.

34 James Dobson, Kendalikan Selagi Mampu (Bandung: Kalam Hidup, 1993), 84.
} 
apatis, kekerasan dan kekejaman. Untuk mengajarkan keadilan pada anak, penting sekali orangtua menunjukkan sikap adil kepada anak-anaknya, tanpa membandingbandingkan nilai rapor, gender, prestasi, dan sebagainya. Kedua: bantu anak agar bersikap adil. Anak tidak hanya menuntut mendapat perlakuan adil, tetapi juga menuntut orang lain diperlakukan dengan adil. Untuk membuat anak mulai memahami keadilan adalah membantu mereka bersikap adil. Belajar berbagi sangat berguna menumbuhkan keadilan. Orangtua dapat mendorong anak untuk berbagi dengan cara menunjukkan pengaruhnya terhadap anak lain. Orangtua mengatakan, misalnya: "Joshua senang bermain di sini karena kamu baik dan mau meminjamkan mainan." 35

Keadilan harus diajarkan kepada anak sejak dini. Keadilan menuntun agar agar memperlakukan oarng lain dengan tidak memihak (adil), sehingga ia mematuhi aturan, mau bergiliran dan berbagi serta berpikiran terbuka dan terdorong membela pihak yang diperlakukan secara tidak adil tanpa memandang agama, kepercayaan, suku, status social, kemampuan, dan sebagainya-semua orang diperlakukan setara alias adil.

\section{Cinta Tanah Air}

Cinta tanah air itu tidak hanya rasa bangga tetapi juga dapat tercermin dari perilaku cinta tanah air dengan rela berkorban demi kepentingan bangsa dan negara. Rasa cinta tanah air dipahami sebagai suatu perasaan mencintai bangsa dengan sepenuh hati sehingga berusaha untuk melindungi dan memajukan kehidupan bangsanya agar dapat berkompetisi dengan bangsa lain. Dalam cinta tanah air tersebut terdapat nilai-nilai kepahlawanan, yakni rela berkorban untuk bangsa dan negara, mencintai adat atau budaya yang ada di budaya yang ada di negaranya dengan melestarikannya dan melestarikan alam dan lingkungan. ${ }^{36}$

Kaidah Kasih yang tertulis di dalam Matius 22:37-39 yaitu kasihilah Allah dan sesamamu manusia seperti dirimu sendiri juga mencakup perilaku yang mencerminkan norma keadilan dan kasih (solidaritas) untuk terwujudnya kesejahteraan semua umat manusia tanpa kecuali. Robert P. Borrong menambahkan bahwa karena kasih Allah menjadi norma moral, itulah sebabnya dapat diimplementasikan sebagai etika biologis, yaitu penghargaan dan penghormatan terhadap seluruh kehidupan. Atas dasar itu, semua umat manusia terpanggil untuk menunjukkan penghargaan terhadap alam dan memeliharanya dengan baik. Hal dilakukan bukan saja karena kita membutuhkan sumber-sumber alam, melainkan terutama karena Allah telah menunjukkan kasih-Nya yang besar kepada kita. ${ }^{37}$

Glen H. Stassen dan David P. Gushee mengatakan bahwa kita adalah bagian dari bumi ciptaan Allah, dan kita bergantung pada bumi ini untuk hidup kita, sama

35 Stevanus, Mendidik Anak, 44.

${ }^{36}$ Laila Fatmawati, Rani Dita Pratiwi, Vera Yuli Erviana, "Pengembangan Modul Pendidikan Multikultural Berbasis Karakter Cinta Tanah Air dan Nasionalis pada Pembelajaran Tematik" Scholaria: Jurnal Pendidikan dan Kebudayaan 8, no. 1, Januari 2018:

37 Robert P. Borrong, Etika Bumi Baru (Jakarta: BPK Gunung Mulia, 2000), 170. 
seperti bumi ini bergantung pada kita untuk kehidupannya. Dalam Matius 6:19-34, Yesus dengan sangat jelas menyatakan bahwa Allah memelihara burung-burung di udara dan bunga bakung di ladang, dan bahwa kita ditempatkan di tengah-tengah komunitas yang dipelihara Allah ini. Banyak perumpamaan Tuhan Yesus yang lain yang menunjuk kepada pemeliharaan Allah untuk pertumbuhan benih, untuk ladangladang, untuk karunia hujan dan sinar matahari bagi semua orang. Semua menyadarkan semestinya bahwa kita berada dalam pemerintahan Allah. ${ }^{38}$

Orang Kristen harus terlibat dalam pemeliharaan Allah terhadap alam ciptaanNya. Orang Kristen harus berpartisipasi dalam pemeliharaan Allah yang berkesinambungan. Penanaman nilai-nilai karakter cinta tanah air bisa diimplemenatsikan di keluarga. Partisipasi perseorangan secara langsung, misalnya membuang sampah pada tempatnya, menggunakan air secara efektif, meminimalkan polusi udara, penananam pohon, tidak melakukan penebangan hutan sembarangan, penataan lingkungan hidup yang bersih di sekitarnya, pola hidup hemat (dengan cara mengurangi gaya hidup mewah dan menggantinya dengan gaya hidup berkecukupan atau mengambil secukupnya), kedisiplinan dalam memanfaatkan benda-benda potensial merusak alam/lingkungan baik melalui penggunaan berulang-ulang maupun melalui daur ulang. Selain itu, orangtu haruslah mendidik anak-anaknya agar mereka sayang tanaman/tumbuh-tumbuhan, sehingga mereka belajar memelihara dan merawat tanaman/tumbuh-tumbuhan. Dengan demikian, terlatihlah mereka dengan pola hidup yang menghargai alam, lingkungan hidup dan dalam hal bertanggungjawab.

Menurut Robert P. Borrong, dengan mempraktikkan pola hidup yang menghargai alam, dan lingkungan hidup, maka manusia dapat hidup menurut irama daur alam, yakni alam, dimanfaatkan sekaligus dipelihara kelestariannya. Untuk maksud itu, maka manusia harus melakonkan perilaku yang menjaga kelestarian alam bukan saja untuk kepentingan alam melainkan sekaligus untuk kenyaman, kesejahteraan dan kesehatan manusia sehingga kualitas hidup manusia lebih terjamin baik pada masa kini maupun di masa depan. Norma moral seperti ini bisa dikembangkan secara perseorangan maupun kelompok masyarakat, misalnya dalam Gereja. $^{39}$

\section{Kesimpulan}

Karakter tidak terpisahkan dari iman Kristen. Kebiasaan kita berpikir dan berperilaku, adalah merefleksikan iman yang kita miliki. Iman memengaruhi cara berelasi dengan diri sendiri dan objek lain, bagaimana kita memandang, menilai dan memperlakukannya. Tepat apa yang dikemukakan B.S. Sidjabat, bahwa iman itu meliputi aspek kognitif sehingga kita mempunyai pengetahuan, pengertian, pemahaman tentang apa dan siapa yang kita imani. Apa dan siapa yang kita imani itu tidak hanya melahirkan kepercayaan dalam bentuk dogma saja, tetapi iman juga mencakup aspek relasional, hubungan dengan diri sendiri, dengan sesama dan

${ }^{38}$ Glen H. Stassen, David P.Gushee, Etika Kerajaan (Surabaya: Momentum, 2008), 576.

39 Borrong, Etika Bumi, 286. 
dengan alam. ${ }^{40}$ Itu artinya iman juga tidak terlepas dari perbuatan. Rasul Yakobus menyatakan bahwa iman tanpa perbuatan pada hakikatnya mati (Yak.2:26). John F. MacArthur menegaskan bahwa iman sejati yang berakar dalam Tuhan Yesus melahirkan perubahan karakter. ${ }^{41}$ Jadi pembentukan karakter sangat terkait dengan kehidupan beriman. ${ }^{42}$

Seperti yang dikemukakan N. T. Wright, seorang Bishop di Inggris, yang dikutip Daniel Nuhamara menyatakan betapa pentingnya karakter Kristiani bagi orang percaya, dan itu bukan hanya tambahan, karena memang iman tanpa perbuatan adalah iman yang mati. Jadi karakter adalah bagian integral dari apa artinya menjadi percaya. ${ }^{43}$

Seperti yang telah dikemukakan di depan, bahwa bangsa ini sedang menghadapi keterpurukan atau kemerosotan karakter, yang nampak dengan maraknya kejahatan, korupsi, tindakan anarkhis, main hakim sendiri, maraknya budaya kekerasan, radikalisme, intoleransi, dan sebagainya. Hal-hal itu merupakan tindakan-tindakan yang setiap saat terjadi dalam lingkungan masyarakat Indonesia.

Lalu, apa peran keluarga Kristen untuk mengatasi keterpurukan atau kemerosotan karakter tersebut? Apa kontribusi bagi pembangunan bangsa ini yang sedang menggalakkan pendidikan karakter menjadi suatu gerakan nasional?

Mendesaknya pembaruan karakter di tengah bangsa dan masyarakat Indonesia ini membutuhkan dukungan semua pihak, termasuk keluarga Kristen. Lagi, N. T. Wright mengingatkan umat Kristen untuk peduli dengan pembangunan karakter. Wright mengemukakan bahwa orang Kristen tidak cukup hanya memupuk keyakinan tentang besarnya naugerah pengampunan dan hidup kekal yang diperoleh karena percaya kepada Tuhan Yesus. Lebih dari itu, menurut Wright, orang Kristen harus membenahi atau transformasi karakternya sebab anugerah keselamatan itu mencakup bertumbuhnya karakter baru dalam kehidupan kita. Orang Kristen mempunyai tugas dan panggilan yaitu berubah dalam karakter dalam peran dan status sebagai milik dan saksi bagi Tuhan Yesus. ${ }^{44}$

Keluarga terus memainkan peran kunci dalam membentuk kepribadian seorang anak sebagai generasi penerus masyarakat dan juga bangsa. Keluarga sampai kapan pun tetap menjadi pusat atau sentral di mana nilai-nilai (values) kebajikan (vitues) dan pola kehidupan seseorang terbentuk (Ul 6:4-9). Keluarga adalah tempat seseorang belajar, dengan cara yang paling praktis dan konkrit.

Di keluarga Kristen melalui tujuh kebajikan utama, yaitu belas kasih, empati, penguasaan diri, rasa hormat, toleransi, adil dan cinta tanah air, sebagai landasan untuk membangun karakter Kristiani anak, dapat memunculkan pribadi-pribadi yang

${ }^{40}$ B.S. Sidjabat, 48.

41 John MacArthur, The Pillars of Christian Character (Wheaten, IL: Crossway Books, 1998)

42 Kehidupan beriman (dalam iman Kristen) hanya bersumber dari kedalaman relasi atau pengenalan seseorang dengan Kristus sebagai Tuhan dan Juruselamatnya. Rasul Petrus mengatakan,"Tetapi bertumbuhlah dalam kasih karunia dan dalam pengenalan akan Tuhan dan Juruselamat kita, Yesus Kristus. Bagi-Nya kemuliaan, sekarang dan sampai selama-lamanya" (2 Ptr.3:18).

43 Nuhamara, "Pengutamaan Dimensi”, 113.

${ }^{44}$ N.T. Wright, After You Believe: Why Christian Character Matters (Harper One, 2010). 
berkarakter. Orang yang berkarakter pasti tidak akan melakukan hal-hal yang diketahuinya salah, karena hal itu bertentangan dengan imannya dan juga suara hatinya yang telah diterangi oleh firman Tuhan. Semua pengikut Kristus juga dipanggil dalam peran sebagai garam dan terang dunia, supaya melalui pembaruan karakter mereka, dapat menjadi saksi Kristus.

\section{Daftar Pustaka}

Borba, Michele. Membangun Kecerdasan Moral. Jakarta: Gramedia, 2008.

Borrong, Robert P. Etika Bumi Baru. Jakarta: BPK Gunung Mulia, 2000.

Dobson, James. Kendalikan Selagi Mampu. Bandung: Kalam Hidup, 1993.

Dykes, David O. Character Out of Chaos. Jakarta: Metanoia, 2007.

Fatmawati, Laila Rani, dkk. "Pengembangan Modul Pendidikan Multikultural Berbasis

Karakter Cinta Tanah Air dan Nasionalis pada Pembelajaran Tematik" Scholaria: Jurnal Pendidikan dan Kebudayaan 8, no. 1(Januari 2018).

Gushee, David P dan Stassen, Glen H. Etika Kerajaan. Surabaya: Momentum, 2008.

Ismail, Andar. Selamat Menabur. Jakarta: BPK Gunung Mulia, 2007.

Ismail, Andar. Selamat Sejahtera. Jakarta: BPK Gunung Mulia, 2005.

Iverson, Dick. dkk., Memulihkan Keluarga. Jakarta: Harvest Publication House, 1991.

Mediatati, Nani. "Implementasi Pendidikan Karakter Di SD Negeri Sidomulyo 04 Kecamatan Ungaran Timur Kabupaten Semarang" Jurnal Satya Widya FKIPUKSW 30, no.2 (Desember 2014).

Manubey, Johana., Degeng, I Nyoman Sudana., Dedi Kuswandi “Pengembangan Bahan Ajar Untuk Menumbuhkan Kelemahlembutan Di Sekolah Minggu" Jurnal Pendidikan: Teori, Penelitian, dan Pengembangan 1, no.3 (Maret 2016).

Mangoenprasodjo A. Setiono dan Hidayati, Sri Nur. Anak Masa Depan dengan Multi Intelegensi Yogyakarta: Pradipta Publishing, 2005.

MacArthur, John. The Pillars of Christian Character. Wheaten, IL: Crossway Books, 1998.

Nuhamara, Daniel. "Pengutamaan Dimensi Karakter Dalam Pendidikan Agama Kristen", Jurnal Jaffray 16, no. 1(April 2018).

Sidjabat, B.S. "Spiritualitas dan Pembentukan Karakter" Jurnal Pengarah (Juli 2010).

Susilo, Willy. Membangun Karakter Unggul. Yogyakarta: Andi, 2013.

Suardana, I Made. "Identitas Kristen Dalam Realitas Hidup Berbelaskasihan: Memaknai Kisah Orang Samaria yang Murah Hati" Jurnal Jaffray 13, no.1(April 2015) http://ojs.sttjaffray.ac.id/index.php/IV71/article/view/115 (diakses 16 November 2018).

Susanta, Yohanes Krismantyo. "Persahabatan sebagai Tema Teologis dan Implikasinya Bagi Kehidupan Bergereja" Dunamis: Jurnal Teologi dan Pendidikan Kristiani 2, no. 2, April 2018 http://www.sttintheos.ac.id/ejournal/index.php/dunamis/article/view/169/132 (diakses 16 November 2018).

Stevanus, Kalis. Mendidik Anak. Yogyakarta: Lumela, 2018.

Stevanus, Kalis. Menjadi Orangtua Bijak : Solusi Mendidik Dan Melindungi Anak Dari Pengaruh Pergaulan Buruk. Yogyakarta: Pustaka Nusatama, 2016.

Tong, Stephen. Membesarkan Anak Dalam Tuhan. Jakarta: LRII, 1997. 
Ulfah, Amaliyah ."Pengembangan Subject Specific Pedagogy (SSP) Tematik Berbasis Local Wisdom Untuk Membangun Karakter Hormat dan Kepedulian Siswa SD", Scholaria: Jurnal Pendidikan dan Kebudayaan 8, no. 1 (Januari 2018).

Wright, N.T. After You Believe: Why Christian Character Matters. Harper One, 2010. 